\title{
Studies on Indigenous Ceremony Values in Strengthening the Character of the Nation
}

\author{
Aprillio Poppy Belladonna \\ Prodi Pendidikan Pancasila dan Kewarganegaraan \\ STKIP Pasundan \\ Cimahi, Indonesia \\ Aprillio_poppy@yahoo.co.id
}

\author{
Ecep Rohmat \\ Sekolah Menengah Atas (SMA) BPS and KI \\ Jakarta, Indonesia
}

\begin{abstract}
Globalization results in a shift in socio-cultural values that cause a crisis of a nation's identity and impact on the degradation of the character of its citizens. The values of the nation's identity can be obtained through local wisdom in the Traditional Ceremony which contains good values and is believed by the community so that it becomes a guide in behaving. Therefore, society can adapt to globalization without leaving tradition. The research method used is a case study method with a qualitative approach, to understand and explain various problems in depth. Data collection is done through documentation, observation, and interviews. The research site of this study was the scope of Mekarsari Village, Bandung Regency, West Java Province, Indonesia. Meanwhile, the subjects of research are a custodian (Juru Kunci), village officials, and local public figures. The results showed that the Traditional Ceremony process contained values in the preparation and implementation stages, especially religious and social values, then, in the stage of equipment used contained symbols that showed the character values of the nation. Maintaining this traditional ceremony is done by embracing the younger generation to know, to understand and to implement it. The aim is none other than the traditional ceremony as Sundanese local wisdom can be sustainable and its existence which also receives real support from the government makes the traditional ceremony a part of efforts to strengthen the character of the nation.
\end{abstract}

Keywords-local wisdom; nation's character; traditional ceremony

\section{INTRODUCTION}

Globalization provides widespread implications for all nations including Indonesia. The entry of a new global culture and its values in every segment of society, in some way shifts the existence of local cultural values that become an indigenous identity of a society [1]. This leads to changes in other aspects of life, such as kindship, social relations, nationality or generally affects the culture of the archipelago with the entry of new values that cause a shift of socio-cultural values of a nation that becomes its identity.

This shift in value is also evident from the behavior of young people today who tend to like the existence of outside cultures rather than their own local culture. This can be seen from many attitudes of young people who begin to behave individually and no longer put forward the courtesy. They put forward individuality rather than collectivity. Not to mention the widespread of consumerism, materialism, hedonism, secularism, glorification of science and technology, promiscuity, violent culture, pornography, porno-action and other unkind characters are becoming increasingly complicated issues experienced by this nation [2].

This fact shows the urgency of character education in the life of Indonesian society. Character education that must be developed is religious values and cultural values of the nation (local wisdom). Local wisdom existing in a society is one of the material contents that must be contained in a character education. The cultural values of other people or other nations can be adopted so far as not to contradict and can develop their own noble cultural values. This understanding is actually inseparable from the basic concept which states that an education is a process of inheriting the cultural values of a society to the next generation so that the education cannot be separated from the culture of society. As stated by Setyarto and Efendi with the correct understanding, the perception of cultural forms as deviant actions can be straightened so that the community is open to seeing the educational aspects contained in it [3].

Totoh Santosa and Endang Komara in Apandi argue that for character education to be more contextual, more operational, and better suited to the needs, situations, conditions, characteristics of society, it is necessary to integrate the values of local wisdom [4]. Character education in the community is a part of the community life itself. So the character values become the beliefs of the community which must be continuously passed on to the next generation to be sustainable and become a guidance in everyday attitude and behavior. This is proven by the persistence of the values of these characters until the present generation. The values of local wisdom through the culture that still exists and is still done by the people of Mekarsari Village Bandung Regency until now as one of the examples of local wisdom through a Huluwotan traditional ceremony which has values that can be used as guidance in community life and make efforts to maintain the culture of archipelago so that can build the character of the nation

Traditional ceremony as a local wisdom is a permanent activity of the Mekarsari Culture Village community in a certain period of time which as a whole involves the community as its supporters. The core values embodied in the 
in indigenous local wisdom of Huluwotan indirectly remind the public of the true identity that must be possessed and to avoid the mindset, attitudes and behaviors that are not original identities. In line with that opinion, according to the value of traditional wisdom values are taught by supporters, actors and implementers of traditional wisdom itself. Therefore, the community can easily receive and understand the contents of the traditional wisdom in depth. Local Wisdom Urgency Forms Nation's Character in the Implementation of Regional Autonomy [5].

In the cultural context, the traditional ceremony of Huluwotan has values that are characterized by the attitude of citizens in the form of: religious values, mutual assistance, responsibility, honesty, hard work, social care, tolerance, deliberation, solidarity and care for the environment, in this case the values of local Sundanese wisdom. Sundanese culture and art are very rich in the values of local wisdom. The values of local wisdom serve as a guide for past predecessors so that they can live harmoniously, respect each other, live side by side with each other and achieve success. Thus, in this study the values of local wisdom that indigenous people taught through a Huluwotan traditional ceremony to the next generation who teaches the character values to the community and do efforts to strengthen the values of Huluwotan traditional ceremony in the face of social and cultural shifts, that through the value of local wisdom, it is an effort to maintain a culture in a nation [6].

\section{THEORETICAL FRAMEWORK}

\section{A. Traditional Ceremony as Sundanese Local Wisdom}

Local wisdom described by Sartini consists of two words, namely wisdom and local [7]. Wisdom has the same meaning as discretion, while local refers to a local region. In general, the meaning of local wisdom can be understood as local ideas which are wise, full of good wisdom embedded and followed by members of the community. Local wisdom is also interpreted by Lubis in the Rancage cultural foundation explaining that traditional wisdom is something that is common in past societies in the local tradition, which is used as a reference for the local life and cultural order [8]. The traditional wisdom can be called as local wisdom. Each community has its own wisdom to maintain unity or interaction as well as the identity of their group or people. Traditional wisdom means a thorough insight or perspective and comes from the tradition of life, because the tradition is a part of the culture, traditional wisdom can differ from one group to another.

Sibarani argues that local wisdom is "remembering the past, understanding the present, and preparing the future" [9]. Remembering the past means trying to unearth past traditions, identifying the past means digging past traditions, sifting through the values of past traditions, and then reaping the valuable things in the past tradition. Understanding the present means knowing the problems of contemporary life with all its advantages and disadvantages as well as providing solutions to the problem by implementing the values of past traditions. Thus, the culture is able to deal with the influence of foreign cultures when they are connected [10]. So, it can be concluded that the local wisdom is the society knowledge derived from experience actualized in the form of activities that become a life guide of the community.

In this research, local wisdom is realized in the form of Huluwotan traditional ceremony which is one of local wisdom in Mekarsari Bandung area. Traditional Ceremony itself is defined by Sinaga in Koentjaraningrat as a social activity involving all citizens, in order to achieve common safety [11]. Humans as social beings have the nature to always work together. This is a basic impulse existing in humans for the sake of preserving their lives.

The existence of custom ceremonial ritual is one of humans' efforts to seek salvation, tranquility, to keep the heritage which is the relic of their ancestors and to maintain the natural environment where they live. Indonesia has diverse ethnic groups and customs, so that the Indonesianis a plural society. Therefore, various kinds of traditional ceremonies that spread in many parts of Indonesia are found. Every ceremony has its own values in which the values can be actualized by the local community. Individuals have responsibilities in the form of rights and obligations to the community, and the community has an obligation to nature [12]. A customary ceremony is a tradition which teaches us that as cultured people, we involve in taking responsibility for preserving nature in its entirety, contributing to improving human dignity in various ways, helping to foster harmony in society, based on the belief that their efforts and actions are in accordance with the natural law which is applicable to every person [13].

According to Koentjaraningrat here are several elements involved in the implementation of traditional ceremonies, among others are [11]:

1) Place of ceremony: The place used to carry out a ceremony is usually a sacred place or holy place, not everyone can visit the place. The place is only visited by interested people, in this case the people are the ones involved in the execution of a ceremony such as a ceremonial leader.

2) Time of ceremony: The timing of the ceremony is a certain time that is felt right to hold the ceremony.

3) Things or tools of ceremony: The objects or tools in the execution of the ceremony is something that should be served. It is a kind of offering that serves as a tool in a traditional ceremony.

4) The people involved in the ceremony: The people who are involved in traditional ceremonies are those who act as ceremonial leaders and some people who understand the rituals of traditional ceremonies.

\section{B. Character Education}

The character of the nation, according to Desain Induk Pembangunan Karakter Bangsa (Master Design of Nation Character Building), is defined as a unique quality of collective nationality behaviors both reflected in the awareness, understanding, taste, intention and behavior of the nation and state from the result of thought, taste and intention, as well as exercises done by a person or group of people. Furthermore, Samani and Hariyanto explain that the character is interpreted as a way of thinking and behaving that is typical of each 
individual to live and work together, both within the family, society, nation and state [14]. Individuals having characters are the ones who can make decisions and are ready to account for any consequences of their decisions. Characters can be regarded as values of human behavior related to God Almighty, ourselves, other people, environment, and nationality embodied in thoughts, attitudes, feelings, words and deeds based on religious norms, laws, norms, culture, customs, and aesthetics. Characters are behavior that appears in everyday life both in attitude and in acting.

In line with that opinion, according to Purwasasmita character building is the process of carving soul in such a way, so that shaped unique, interesting, and different from or can be distinguished with others [15]. The character building process requires high discipline because it is never easy and instant. It takes a deep reflection to create a barrage of moral choice and is followed up with concrete action to become praxis, reflection, and practice. It takes a certain amount of time to make all custom and shape one's character. Six pillars of characters building are trustworthiness, respect, responsibility, fairness, caring, and citizenship. Thus, character education can be defined as an education to "shape" a person's personality through character education, in which the results are seen in one's actual actions, namely good behavior, honesty, responsibility, respect for the rights of others, hard work and so on [16].

Furthermore, the concept of good character popularized by Lickona which refers to the concept proposed by Aristotle as ".... the life right conduct-right conduct in relation to other persons and in relation to oneself' or a life of good or benevolent behavior, that is to behave well toward others (God Almighty, human, and universe) and to self. The virtuous life has been divided into two categories by Lickona which are self-oriented virtuosity such as self-control and moderation; and other-oriented virtuosity, such as generosity and compassion [16].

Moreover, it is stated that substantively there are three behavioral ratios (operatives, values, values in action) of each other are related to moral knowing, moral feeling, and moral behavior. Further affirmed that good character consists of psychological process of knowing the good, desiring the good and doing the good - habit of the mind, habit of the heart, and habit of action. The values taught in Character Education, as described above, emphasize the importance of three character components. Moral knowing or moral knowledge involves moral awareness, knowing moral values, perspective taking, moral reasoning, decision making, and self-knowledge.

The need for character education is also explained by Lickona, Suyatno which reveals several key reasons, among which are: (1) The large number of young people were harming each other due to lack of awareness of moral values, (2) giving moral values in the younger generation is one of the most important functions of civilization, (3) the role of schools as character educators becomes increasingly important when many children gain some moral teaching from parents, communities, or religious institutions, (4) there has still moral values universally accepted such as care, belief, respect and responsibility(5) Democracy has a special need for moral education because democracy is a rule of, for and by society, (6) There is no such thing as value-free education, schools teach values every day through design or without design, (7) Commitment to the character education is important if we want and continue to be a good teacher, and (8) Effective character education makes schools more civilized, caring for the community, and refers to improved academic performance [17].

Based on the exposition of opinion above, each person has his/her own characters, and the characters themselves should be formed so that they lead to be good ones. This is the view that the importance of the character applied to the community as a citizen, one of them is through the Sundanese local wisdom in the form of Huluwotan Traditional Ceremony that has good values that will form good character. Thus, the nature and behavior of good and responsible citizens provide benefits for the life of society, nation, and state. Thus, Character and behavior of good and responsible citizens provide benefits for the life of society, nation and state [18].

\section{METHOD}

This study employed a qualitative approach embracing a case study research method. The researcher chose the case study method because this method captured an in-depth and detailed studyof certain individuals, groups, organizations or phenomena. A typical phenomenon of this study is thatthe values of Sundanese local wisdom which are still present and done by the community of Desa Mekarsari Bandung to date is Huluwotan Traditional Ceremony expected to serve as an effort to maintain the culture of the archipelago so that it is able to build the character of the nation.

The research site of this study was the scope of Mekarsari Village, Pasir Jambu District, Bandung Regency, West Java Province, Indonesia. Meanwhile, the subjects of research are a custodian (Juru Kunci), village officials, andlocal public figures.

Data collection techniques used in this study were interviews, observation, documentation studies, and literature studies. Qualitative data analysis during instudy in the field on the basis of Miles and Huberman's model consists of four activities, namely data collection, data reduction, display data and conclusion drawing/verification. In a qualitative research, findings or data are valid if there are no differences between what the researcher reports and what actually happens to the object under the study. Therefore, the researcher examines the degree of trust or credibility by extending the observation period, carrying out careful observation continuously, implementing the triangulation of the data, using sufficient references, and employing member check.

\section{RESULT AND DISCUSSION}

\section{A. Implementation of Huluwotan Traditional Ceremony as Sundanese Local Wisdom}

The result of research that shows the beginning of the implementation of Huluwotan traditional ceremony is a vow an elder named Abah Apung or Abah Lebe. At that time the 
villagers of Kampung Gambung lack of water, than the residents led by the village elders agreed to build a solokan or water channel that is approximately 2 kilometers long. The construction of solokan starts from Huluwotan (spring) at the foot of Mount Geulis to the settlement. As stated by Koentjaraningrat that the ceremony is an activity system or series or action that is governed by custom or law which is applicable in society related to various fixed events that usually occur in the society concerned [11]. The Implementation of Huluwotan traditional ceremony is a message of ancestor of Gambung community, which is inherited to their offspring. Gambung residents do not dare to leave the Huluwotan ceremony. Therefore, the ceremony is one of tradition and society is very concerned with this activity.

Huluwotan is a routine ceremony performed from generation to generation. This shows a form of societies' behavior who are aware of their past [19]. Through the ceremony, we can trace the origin of the place, character, things, natural events and so on. Based on the opinions above, it can be concluded that Huluwotan traditional ceremony conducted by the community of Mekarsari Village is a local wisdom created by the community itself based on the knowledge they have in order to remember by tracing the merit of elders or in Sundanese it called napak tilas karuhun. This is in line with the opinion of Aminudin [20] who states that local wisdom is a noble culture created by an ancestor through an experience that eventually becomes a certain pattern and rules.

According to interviews that researchers did with the caretaker and local public figure, the purpose of the implementation of Huluwotan ceremony is as an expression of gratitude or as a means of conveying thanks to the Almighty over the blessings that are given, especially those concerning the source of the springs. In line with the opinion of the interview, Rostiyani stated that the function of the ceremony is the spiritual function about the individual approach to his God. In addition George Sinneal in Rostiyani suggests that, an important aspect of belief is the formation of religious relationships. In that respect, human beings tend to model relationships with God, gods, spirits and supernatural powers [21].

Ovrianti suggests that, in traditional ceremonies in general, it aims to honor, be grateful, adore, plead for salvation to God through creatures and ancestors [19]. The existence of traditional ceremonies is a human effort to seek safety, peace, while preserving their customs. This salvation is essentially the most common religious event in the world and symbolizes the mystical and social unity of those who attended the ceremonies.

Based on the results of interviews that researchers did with the caretaker local public figure, it was found that parties who always play an active role in Huluwotan traditional ceremony is all citizens of Mekarsari village community. In line with the results of interviews conducted by researchers on the parties who play an active role in the implementation of Huluwotan traditional ceremony, in his view argued that a traditional ceremony is a social activity involving all citizens, for the achievement of safety together. According to the presence of members of relatives, neighbors and friends in a ceremonial activity shows a high value of solidarity on the basis of kinship and neighboring values. Humans as social beings have the nature to always work together. This is a basic impulse in him, in order to preserve and preserve his life.

According to the results of interviews carried out by researchers with the caretaker, the village secretary, and the local public figure, there are two events held in the implementation of Huluwotan ceremony namely the procession or convoy and entertainment. The procession is an early ritual performed in a series of Huluwotan ceremony activities. The procession starts from the village office to the water source or Huluwotan in the Ciawitali area, around the foot of Mount Tilu and Mount Geulis where the ritual is held in the month of mulud (Rabiul Akhir).

On the basis of the results of interviews that have been described above, the researchers concluded that the Huluwotan tradisional ceremony contains several elements including; preparation and implementation that should be prepared, the parties involved in the implementation of traditional ceremony of Huluwotan, the place and time, the stages and the prohibition which must be obeyed during the Huluwotan traditional ceremony occurs.

\section{B. Values of Character Contained in the Implementation of Huluwotan Traditional Ceremony}

Based on the results of interviews conducted by researchers, it is revealed that the value embodied in the implementation of Huluwotan traditional ceremony isa religious value where the main purpose of the implementation of Huluwotan traditional ceremony is to express gratitude to the presence of Allah SWT, to express obedience, sincerity, sacrifice, dedication, faith and devotion. Then the social value that can be seen from the preparation and the implementation of the traditional ceremony is a consensus to reach mutual agreement, mutual assistance, kinship, preserving the environment by cleaning water sources and planting plants, and preserving the arts and culture owned.

Meanwhile, the caretaker and public figure stated that the equipment prepared to carry out the traditional ceremony is symbol that contains the values of life, such as:

- A black goat or embe hideug symbolizesthat man must act maturely. The head of a buried goat implies that the animalistic behavior that exists in the human being must be eliminated. It contains the character value of sincere, sympathy, empathy, and compassion.

- Coconut water symbolizes that man must have a strong belief to get happiness. It contains the character value of honest, responsible, discipline, independent and hardworking.

- Spices such as red chilies, areuy chilies or Javanese long peppers (piper retrofractum), cardamom, and cloves that taste hotsymbolize the sense of joy or happiness which means that people should live in harmony and in peace. This contains the character values of tolerance, communicative and social caring. 
- Manggala tree (a kind of banana tree) symbolized that every speech should have clear content and purpose. It contains the character value of democratic.

- Hanjuang hejo (a green cordyline) symbolizes that man must have a guideline of life. It contains the character value of appreciating an achievement.

- Jaringao which means jaringan roh rongrong gogodongan is keep the human spirit from magical temptation.

- Jukut palias (Palias grasses) symbolizes not to take a life if God doesn't do it. It contains the value of religious character describing the obedient attitudes and behaviors in implementing the teachings of religion that ones follow.

- Black taro symbolizes that man must be sincere in receiving ordeals. It contains the character value of tolerance.

- Sugarcane symbolizes ulah luntur ku ibun laas ku hujan which means that man must live toughly and not weakly. It contains the character value of hard-working, creative and independent.

From the results of the research, it can be obtained that the equipment prepared to carry out the Huluwotan traditional ceremony has symbols that contain meaning and values that are beneficial to human life. In line with the results of the interview, Hermansyah in Rostiyani suggests that: Traditional ceremonies need to be maintained because they contain positive values which are beneficial to people's lives [21]. Positive values or norms contained in the traditional ceremony provide a very important contribution, so that people can interact effectively and orderly in undergoing various activities in their lives. This is because each value has emotional contents and logical ideas that are able to curb negative actions and generate positive behavior in society.

Referring to the above opinions, the researchers believes that the implementation of Huluwotan traditional ceremony is one of the efforts made by Mekarsari villagers to convey the values existing in it. The effort can be related to the nation's character building efforts. This can be seen from the values:

- Based on the results of interviews with the caretaker, the values contained in Huluwotan traditional ceremony are good values and are believed by the community, so these values become the guidelines in behaving. Besides that, the village secretary revealed that, so far, people live harmoniously and there are no bad reports about them. Perhaps, it happens because the villagers believe that the implementation of Huluwotan traditional ceremony have core values that must become a guideline to take action. In addition, the local public figure stated that the values which are present in Huluwotan traditional ceremony become the community's life guidelines in socialization, because it is believed that the values are guidelines in acting and behaving so that the community can live harmoniously and peacefully.
- The values existing in the Huluwotan traditional ceremony are to make the community always grateful to the presence of Allah SWT andto experience the harmonious life. Then, the secretary of the village revealed that the benefits received by the community from the values contained in Huluwotan traditional ceremony can be felt if they recallthe elders' merit who struggle to drain the water. The community gets wisdom that they should not be lazy. Being always grateful to Allah SWT, being able to live side by side in peace, and doing everything with mutual cooperation makes work light.

Referring to the explanation above, the researchers conclude that the impact of the strengthening of local wisdom values of Huluwotan traditional ceremony both in purpose, preparation, implementation, and equipment prepared in the Huluwotan traditional ceremony as an effort to build the nation character in Mekarsari village, is in line with the values of Pancasila which became the main basis of the attempt of the nation character building. The characters of the Indonesian nation entirely and comprehensively imbued by the five precepts of Pancasila according to Desain Induk Pembangunan Karakter Bangsa (The Main Design of Nation Character Building) of the Year 2010-2025 in Rasid Yunus are as follows [22]:

1) The Nation that believes in the one and only God: Having a belief in the one and onlyGod is a form of behavior awareness of faith, devotionand noble character as personal characteristics of the Indonesian nation. A belief-in-God character is reflected in, among others, respect for and cooperation between believers; respect formutual freedom of worship in accordance with religion and its believers; not imposingreligion and belief on others. This is reflected in the Mekarsari villagers. Although the majority of Mekarsari villagers are Muslim, the religious density is well preserved. Another thing which is also reflected in the purpose of the implementation of Huluwotan traditional ceremony is as gratitude to Allah SWT on the grace of water given as a source of life.

2) A nation that upholds a just and civilized humanity: Attitudes and behavior upholding a just and civilized humanity are manifested in respectful behavior among citizens as a personal characteristic of the Indonesian nation. The character of one's humanity is reflected in, among others, in the recognition of equality, rights and obligations; loving each other; tolerance; not arbitrary against others; loving to do humanitarian activities; upholding the value of humanity; daring to defend truth and justice; feeling themselves as a part of all humans and developing a respectful attitude. This is reflected in the implementation of Huluwotan traditional ceremonies where Mekarsari villagers are gathered in one event and feel the warmth of kinship.

3) The Nation that promotes its unity: Commitment and attitude that always prioritize the unity of Indonesia before personal and group's interests are the personal characteristics of the Indonesian nation. The character of one's nationality is 
reflected in the attitude of putting the unity, interest and salvation of the nation before personal and group's interests; willing to sacrifice for the benefit of nation and state. This is reflected in the implementation of Huluwotan traditional ceremony where the activity is done with mutual-cooperation.

4) A democratic nation which upholds the law and human rights: Democratic attitudes and behavior based on values and democratic spirit led by the wisdom of the representatives of the peopleare the personal characteristics of Indonesian citizens. A person's democratic character is reflected in behavior that prioritizes the interests of society and the state; not to impose will on others; prioritizes deliberation to consensus in making joint decisions; and has good intention and is responsible in carrying out the joint decisions. In the village of Mekarsari, this is reflected in the preparation of the Huluwotan traditional ceremony, in which before the event is carried out, the community holds a meeting to obtain joint decisions.

5) A nation that promotes justice and prosperity: Commitment and attitude to bring about justice and prosperity are the personal characteristics of the Indonesian nation. The character of social justice is reflected in actions that reflect the attitude and the atmosphere of kinship and mutual cooperation, justice, and that maintain the harmony between rights and duties, respect for the rights of others, helping others, avoiding the extortion of others, not wasteful, not living large, hard-working, and appreciative of the work of others. In Mekarsari Village, this is reflected in the implementation and the equipment prepared to hold the Huluwotan traditional ceremony.

The nation character building is an effort made through a systematic plan and involves all elements of government, society, and education. In addition to these elements, there is the most important thing that is what values are used in the process of building a nation's character. According to Desain Induk Pembangunan Karakter Bangsa Master Design of the Nation Character Building in Yunus, it is stated that the nation character building is a systematic collective effort of a nationstate to realize the life of the nation and its country based on the basis and ideology, constitution, state direction, and its collective potential in the context of national, regional, and global civilized life [22].

Based on the explanation from the Master Design of the Nation Character Building above, it can be understood that the character building of the nation can be carried out through the ideology, constitution and collective potential of a country. Collective potential in question is the local wisdom owned by the Indonesian nation.

Building the character of the nation is an effort made through a systematic plan and involves all elements of government, society, and education. In addition to these elements, there is the most important thing that is what values are used in the process of building a nation's character. According to Desain Induk Pembangunan Karakter Bangsa Master Design of the Nation Character Building in Yunus, it is stated that the nation character building is a systematic collective effort of a nation-state to realize the life of the nation and its country based on the basis and ideology, constitution, state direction, and its collective potential in the context of national, regional, and global civilized life [22].

\section{Efforts to Preserve the Huluwotan Traditional Ceremony as a Way of Nation Character Building}

Based on the interview, the caretaker and the village secretary revealed that the obstacles in maintaining the Huluwotan traditional ceremony is the development of science and modern technological advances that are fast enough and that demand everyone to think logically and practically. Referring to the result of the interview, the researchers hold that the Huluwotan traditional ceremony as the local wisdom of the Mekarsari villagers is faced with the development of the era caused by the influence of globalization with the characteristics uncovered by an informant that is the increasingly evolving science and progress of modern technology which increase rapidly. In her research revealed, That the indication of cultural traditions that are natural and mythological facts begin to be abandoned by some people [23]. In line with the opinion from the results of the interview, Suhartini reveals that the local wisdom has various challenges such as; continuous increase in population, modern technology and culture, large models as well as poverty and inequalities [24].

Reveals that globalization as an indication of change in a society that almost sweeps across the nation is often perceived as a threat and challenge to the integrity of a country [7]. Thus, if a country has a particular local identity, in this case local wisdom or local culture, it cannot be separated from the effects of the globalization so that local wisdom must remain alive and keep up with the times. Given that globalization marked by the development of science and technological progress has become parts of Mekarsari villagers' life, it is necessary to maintain the Huluwotan traditional ceremony.

Explained cultural preservation that demands the active role of institutions and village stakeholders who must cooperate with the community in maintaining cultural values and local wisdom [25]. Cultural values are references for fulfilling the needs of courtesy, namely the needs to know the right as opposed to the wrong, the holy from the dirty, the good from the bad, and so on. The cultural value possessed by a society is not static, but continues to shift and change from one generation to the next one [26].

On the basis of the interviews with the caretaker, a way to maintain the Huluwotan traditional ceremony is to socialize and introduce the culture possessed by embracing young generation as the next generation so that they participate in preserving it. In line with the opinion of the interview result, Ranjabar reveals that conservation is an effort having a foundation and this foundation is also called factorsthat support, from both inside and outside, what is being preserved [27]. Therefore, a process or act of conservation recognizes both strategies and technique based on each need and condition.

Maintaining the Huluwotan traditional ceremony is very necessary, this is done so that the Huluwotan traditional ceremony as the local wisdom of Mekarsari villagers is not 
eroded by the development of the times. Maintaining the Huluwotan traditional ceremony can be done by preserving it from generation to the next generation so that they do not lose the culture of their identity. A traditional ceremony conducted by citizens has values that must be obeyed by every citizen as supporter. These values grow and develop automatically and are inherited from generation to generation [28]. In line with the opinion, according to [29], ways to preserve traditional culture are carried out by involving young people in terms of committee, as well as implementation, so that the young generation not only becomes committee but also actors. The implementation of traditional activities contains values: divine values, social values, values of harmony, cultural values, historical values, entertainment values, educational values, and scientific values. Traditional activities continue to be carried out, with the aim that the pluralistic Indonesian society does not lose their regional culture.

The caretaker reveals "jalmi nu teu ngamumule kana budaya moal apal dirina" which means if one does not preserve his own culture then he will not know what his real identity is. Likewise, Lubis states that national identity is a cultural character that functions as a nation character building. Furthermore, the village secretary and the local public figure revealed that the way to maintain the Huluwotan traditional ceremony is to convince the community that the Huluwotan traditional ceremony is an activity with good intent and is a space where art and culture can be strengthened to be defended. In line with the opinion of the interview result, [30] reveals the purpose of cultural preservation is to revitalize or strengthen the culture. Referring to the informant and Alwasilah's opinion, the researchers hold that the Huluwotan traditional ceremony is held as one of Mekarsari villagers' efforts to achieve cultural revitalization, so as to avoid shocks in the midst of globalization. So that people get the balance of life in which people are able to adapt to globalization without leaving the tradition.

Maintaining the Huluwotan traditional ceremony is the joint task of both society and government, in the 1945 Constitution article 32 paragraph 1, it is stated that: "The country promotes the national culture of Indonesia amidst the civilization of the world by ensuring the freedom of the community in maintaining and developing cultural values". It has also been mentioned by Alus that cultural preservation demands an active role of institutions and village stakeholders who must cooperate with the community in maintaining cultural values and local wisdom [24]. Therefore, the government must take part in maintaining the Huluwotan traditional ceremony. Based on the results of research, this support has been given because the Tourism and Culture Office has recognized Mekarsari Village as one of 10 Tourism Villages and 5 Cultural Villages in Bandung since 2011. Since then, Huluwotan traditional ceremony has become the activity agenda in the Regency whose purpose is none other than to introduce and preserve the Huluwotan traditional ceremony.

\section{CONCLUSION}

The destruction of the nation's identity with the degradation of citizens' character causes local wisdom preserved through the Huluwotan Traditional Ceremony to be used as a means of building the nation's character. The life view of the Mekarsari Village community is "jalmi nu teu ngamumule kana kabudayaan, moal apal jati dirina" which means that if humans do not preserve their own culture then they will not know what their true identity is, making guidelines for them to continue to carry out the Huluwotan Traditional Ceremony. The values contained in the preparation and implementation stages are mainly the value of mutual cooperation and religion, the stage of equipment used also contains symbols and character values such as sincere, sympathy, and empathy, honest, responsible, disciplined, communicative, socially caring, democratic, respect for achievement, tolerant, hardworking, creative and independent. Therefore, local wisdom of the Huluwotan Traditional Ceremony can have positive influences on the success of nation character building. Despite the development of the era and the entry of new values due to the advance of the world, this traditional ceremony can survive by involving young people to recognize, to understand and to preserve Huluwotan traditional ceremony continuously from generation to generation so that it can provide behavior guidelines for the local community. Support from local governments that significantly contribute to preserving the Huluwotan traditional ceremony in which, since 2011 the Tourism and Cultural Office has recognized Mekarsari Village as one of 10 Tourism Villages and 5 Cultural Villages in Bandung (West Jawa-Indonesia) Regency. Since then, the Huluwotan traditional ceremony has become an activity put in an agenda in the Regency whose purpose is none other than to introduce and preserve the Huluwotan traditional ceremony as a vehicle for the nation character building.

\section{REFERENCES}

[1] Safri, "Strategi Meningkatkan Daya Tahan Budaya Lokal dalam Menghadapi Arus Globalisasi," Jurnal Masyarakat, Kebudayaan, dan Politik, vol. 24, No. 4, 2011.

[2] Abdallah, Kafa, dan P. Parama Pinurba, "Kearifan Lokal Sebagai Benteng Karakter Bangsa: Studi Kasus Tradisi Pernikahan Adat Jawa Ala Kadipaten Pakualaman - Yogyakarta," Jurnal Etnografi, vol. XVI, No. 1 .

[3] Setyarto, Rahayu and A. Efendi, "Jurnal Ilmu Komunikasi, vol. 12, No. $1,2014$.

[4] I. Apandi, Revolusi Mental Berbasis Pendidikan Karakter (Permasalahan, Tantangan dan Solusi Implementasi Pendidikan Karakter sebagai Bagian dari Revolusi Mental di Indonesia), Bandung: Fajar Media, 2015.

[5] Marpaung, and A. Lintje, "Urgensi Kearifan Lokal Membentuk Karakter Bangsa Dalam Rangka Pelaksanaan Otonomi Daerah," Yustisia Jurnal Hukum, vol.2, No.2, 2013.

[6] Prayogi, Ryan and E. Danial, "Pergeseran Nilai-Nilai Budaya Pada Suku Bonai Sebagai Civic Culture Di Kecamatan Bonai Darussalam Kabupaten Rokan Hulu Provinsi Riau)," Humanika, vol. 23, No. 1, 2016.

[7] Sartini, "Menggali Kerifan Lokal Nusantara Sebuah Kajian Filsafat." Jurnal Filsafat, vol. 37, No. 2, 2004.

[8] N.H. Lubis, Tradisi dan Transformasi Sejarah Sunda, Bandung: Humaniora Utama Press, 2001.

[9] R. Sibarani, Kearifan Lokal: Hakikat, Peran dan Metode Tradisi Lisan, Jakarta: Asosiasi Tradisi Lisan, 2012.

[10] A. Rosidi, Kearifan Lokal (dalam Perspektif Budaya Sunda), Bandung: Kiblat Buku Utama, 2011. 
[11] Koentjaraningrat, Sejarah Teori Antropologi 1, Jakarta: Universitas Indonesia, 1980.

[12] R.G. Axiaverona, dan R.B. Soemant, "Nilai Sosial Budaya Dalam Upacara Adat Tetaken (Studi Deskriptif Upacara Adat Tetaken di Desa Mantren, Kecamatan Kebonagung, Kabupaten Pacitan)," In Journal of Development and Social Change, vol. 1, No. 1, 2018.

[13] Abadi and Soebijantoro, "Upacara Adat Ruwatan Bumi Di Kelurahan Winongo Kecamatan Manguharjo Kota Madiun (Latar Sejarah, NilaiNilai Filosofis, Dan Potensinya Sebagai Sumber Pembelajaran Sejarah Lokal)," Jurnal Agastya, vol. 6, No, 1, 2016.

[14] M. Samani, and Hariyanto, Konsep dan Model Pendidikan Karakter, Bandung: Remaja Rosdakarya, 2012.

[15] M. urwasasmita, "Memaknai Konsep Alam Cerdas dan Kearifan Nilai Budaya Lokal (Cekungan Bandung, Tatar Sunda, Nusantara, dan Dunia) Peran Local Genius dalam Pendidikan Karakter Bangsa," Prosiding Seminar, Bandung: Widya Aksara Press, 2010.

[16] T. Lickona, Educating for Character: How Our Schools Can Teach Respect and Responsibility, New York: Simon and Schuster, Inc, 1992.

[17] Suyatno, Peran Pendidikan Sebagai Modal Utama Membangun Karakter Bangsa, Jakarta: Makalah Saresehan Nasional, 2010.

[18] Mahardika, I Wayan Trisna, and C. Darmawan, "Civic culture dalam Nilai-Nilai Budaya dan Kearifan Lokal Masyarakat Bali Aga Desa Trunyan, Jurnal Humanika, vol. 23, No.1, 2016.

[19] D. Ovrianti, Kajian Nilai-Nilai Budaya Upacara Adat Nyangku Dalam Kehidupan di Era Modernisasi (Studi Deskriptif di Desa Panjalu Kabupaten Ciamis), 2015.

[20] Aminudin, Menjaga Lingkungan Hidup dengan Kearifan Lokal, Jakarta: Titian Ilmu, 2013.
[21] A. Rostiyati, Fungsi Upacara Tradisional Bagi Masyarakat Pendukungnya Masa Kini, Yogyakarta: Departemen Pendidikan dan Kebudayaan, 1995.

[22] R. Yunus, Nilai-Nilai Kearifan Lokal (Local Genius) sebagai Penguat Karakter Bangsa Stusi Empiris tentang Huyula, Yogyakarta : Budi Utama, 2014.

[23] Pujiwiyana, "Perubahan Perilaku Masyarakat Ditinjau Dari Sudut Budaya," Jurnal Seni dan Budaya, vol. 1, No.1, 2010.

[24] Suhartini, Kearifan Lokal Masyarakat dalam Pengelolaan Sumber Daya Alam dan Lingkungan, 2009.

[25] C. Alus, "Peran Lembaga Adat dalam Pelestarian Kearifan Lokal Suku Sahu di Desa Balisoan Kecamatan Sahu Kabupaten Halmahera Barat, Jurnal Acta Diurna, vol. III, No.4, 2014.

[26] P. Suparlan, Bhinneka Tunggal Ika: Keanekaragaman Suku Bangsa atau Kebudayaan, Jurnal Antropologi Indonesia, vol. 72, No.1, 2003.

[27] J. Ranjabar, Sistem Sosial Budaya Indonesia Suatu Pengantar, Bandung: Ghalib Indonesia, 2006.

[28] P. Fatmawati, "Nilai-Nilai Dalam Upacara Assunna Pada Masyarakat Jeneponto Provinsi Sulawesi Selatan," Jurnal Walasuji, vol 6, No. 1, 2015.

[29] S. Muryati, and Srihadi, Pelestarian Budaya Nasional Melalui Kegiatan Tradisional, Jurnal, vol. 20, No.3, 2013.

[30] A.C. Alwasilah, Pokoknya Sunda, Interpretasi Untuk Aksi, Bandung: Kiblat buku Utama, 2006. 